\title{
Diel density variation of amphipods associated with Sargassum beds from two shores of Ubatuba, Southeastern, Brazil
}

\author{
Fosca P. P. Leite ${ }^{1}$, Marcel O. Tanaka², Daniela B. Sudatti ${ }^{1} \&$ Raquel S. Gebara ${ }^{1}$ \\ 1. Departamento de Zoologia, Instituto de Biologia, Universidade Estadual de Campinas, Caixa Postal 6109, 13083-970 Campinas, SP, \\ Brazil. (fosca@unicamp.br) \\ 2. Departamento de Hidrobiologia, CCBS, Universidade Federal de São Carlos, Caixa Postal 676, 13565-905 São Carlos, SP, Brazil.
}

\begin{abstract}
Densities of mobile epifaunal assemblages associated with macrophytes are very variable during the day and the activity of visually-oriented predators is thought to have an important influence on this pattern. Here we compared densities of amphipods associated with a common brown alga, Sargassum stenophyllum (Phaeophyceae), at sites contrasting in water turbidity. We expected that diel variation of amphipods would occur in a shore with clear waters (Perequê), whereas no variation was expected in a shore with turbid waters (Lamberto). Amphipod density varied during the day at both shores, with no indication of a larger variation at Perequê. Most species showed two density peaks, one at night and the other in the afternoon. These peaks occurred close the times of high tide, suggesting that tidal rhythms could influence more amphipod densities than the activity of predators. Thus, more studies are necessary to understand factors that influence short-term variation of epifaunal assemblages.
\end{abstract}

KEYWORDS. Diel variation, amphipods, Sargassum.

RESUMO. Variação ao longo do dia na densidade de anfípodos associados a bancos de Sargassum em duas praias de Ubatuba, SP, Brasil. As densidades da epifauna móvel associada a macrófitas variam muito ao longo do dia, sendo a atividade de predadores visualmente orientados um dos principais fatores apontados para explicar este padrão. Neste estudo, comparamos as densidades de anfípodos associados a uma alga parda comum, Sargassum stenophyllum (Phaeophyceae), em praias contrastando em turbidez da água. Era esperada a ocorrência de variação ao longo do dia numa praia com águas claras (Perequê) e nenhuma variação na praia com águas turvas (Lamberto). A densidade de anfípodos variou ao longo do dia em ambas as praias, sem indicação de maior variação em Perequê. A maioria das espécies apresentou dois picos de densidade: um à noite e outro à tarde. Estes ocorreram próximos aos períodos de maré alta, sugerindo que o ritmo de maré poderia influenciar mais as densidades de anfípodos que a atividade de predadores. Assim, mais estudos são necessários para se compreender os fatores que influenciam a variação de curto prazo das comunidades epifaunais.

PALAVRAS-CHAVE. Variação temporal, anfípodos, Sargassum.

Macrophyte-associated assemblages are important components of the diversity of coastal habitats, because the presence of macrophytes adds complexity to these habitats, increasing the availability of food resources and refuges against predators (CONNOLLY, 1997; PARKER et al., 2001). In tropical and subtropical systems, amphipods generally dominate these assemblages, followed by other organisms such as gastropods and polychaetes (TANAKA \& LeITE, 2003). Several factors influence macrophyteassociated assemblages at distinct spatial scales: at large scales, differences in environmental conditions such as turbidity, hydrodynamics, and salinity can influence species distribution; whereas at smaller spatial scales biological factors such as recruitment, predation, and competition can play a major role (MOORE, 1978; NELSON, 1979; Edgar, 1983; TANAKa \& Leite, 2003).

Predation has a strong effect on the distribution of coastal organisms, and several studies suggest that macrophyte-associated assemblages are influenced by predators, as potential preys try to minimize predator success (Nelson, 1979; HAY, 1997). For example, mobile epifauna can associate with substrates less susceptible to predators due to the presence of chemical defenses (HAY et al., 1987), or present activity patterns that differ from that shown by predators, mainly those which are visually oriented (ROGERs et al., 1998; LINKE et al., 2001). In this case, some studies found greater activity of macro invertebrates at night in periods of new moon, when compared with densities during the day or full moon nights, although variation among faunal groups has been found (TAYLOR, 1998; SÁNCHEZ-JEREZ et al., 1999; LiNKE et $a l ., 2001$; JøRGENSEN \& CHRISTIE, 2003). The pattern of diel variation in activities has been found in other systems as well, with higher nocturnal densities of zooplankton (HAYs, 2003), nekton (Guest et al., 2003) and infaunal benthic assemblages (AlLDREDGE \& KING, 1985).

Most studies comparing the activity of macrophyteassociated assemblages were carried out in a restricted area or in similar areas, ignoring environmental differences in the patterns described (TAYLOR, 1998; SÁNCHEZ-JEREZ et al., 1999). However, turbidity can promote variation between areas in the faunal distribution, by reducing predation pressure due to lower efficiency of prey location and capture in more turbid waters, or influencing predator densities (Moore, 1978). Thus, we evaluated the general hypothesis that diel activity patterns of macrophyteassociated assemblages differ between shores with distinct degrees of turbidity. We expected that in a shore with turbid waters there would be no difference in faunal densities between diurnal and nocturnal periods, whereas in a shore with clear waters densities would be higher at night. We also expected that free-living animals densities would be highest during new moon periods, when visually-oriented predators would be less active. 


\section{MATERIAL AND METHODS}

This study was carried out at Lamberto and Perequê, two shores in Ubatuba district $\left(23^{\circ} 32^{\prime} \mathrm{S}, 45^{\circ} 10^{\prime} \mathrm{W}\right)$, SP Brazil. Both shores are semi-sheltered and located close to each other. Based on a visual assessment, Lamberto presents turbid waters, whereas Perequê, clear waters. The climate is subtropical, with rainy summers and dry winters, and the air temperature varies from 19.5 to $25.9^{\circ} \mathrm{C}$ during the year. The sublittoral of both shores is dominated by boulders of several sizes, which are in turn colonized by different species of brown algae Sargassum spp. (Phaeophyceae), which are common to several shores in the region (SzÉCHY \& PAULA, 2000). In the studied shores, we found dominance of S. stenophyllum.

Sampling was carried out on 11-12 (full moon) and 25-26 (new moon) April 1998, when maximum faunal densities are found, mainly amphipods (TANAKA \& LEITE, 2003). During the full moon period, we sampled algae at $3 \mathrm{~h}$ intervals, throughout a cycle of $24 \mathrm{~h}$. Tides in these regions are semidiurnal type, with minimum low tides occurring around 09:00 am and 9:00 pm and maximum high tides at 02:00 am and 2:00 pm. Low tides were $0.1 \mathrm{~m}$ high, whereas high tides were $1.2 \mathrm{~m}$ high (HARARI \& Mesquita, 1996), resulting in a tidal amplitude of $1.1 \mathrm{~m}$. The sunrise ocurred at 06:16 am and sunset at 5:45 pm, whereas during new moon period, sunrise was at 06:22 am and sunset at 5:34 pm. There were few clouds during sampling times.

During each underwater sampling, we randomly collected three fronds from Sargassum beds by enclosing each alga with a plastic bag and detaching gently its holdfast from the rock with a knife. In the laboratory, we processed the material following TANAKA \& LEITE (1998) to extract amphipods, which dominated the macrofauna. We used a sieve of $0.250 \mathrm{~mm}$ to separate the macrofauna, and the wet weight of each plant was determined to the nearest $0.01 \mathrm{~g}$. In order to evaluate the effect of different moon phases, another sampling cycle was carried out during new moon; however, due to logistical problems, we could only determine the density of caprellid amphipods. Times and height of high and low tides were similar to the full moon period, although low tide was $0 \mathrm{~m}$ high, resulting in a tidal amplitude of $1.2 \mathrm{~m}$.

We evaluated the variation in amphipod densities with a 2-factor fixed effect ANOVA (shore and sampling time). Data were previously transformed to logarithms to obtain homogeneity of variances. To test the hypothesis that assemblage composition varied during the day, we compared the amphipod assemblages with multidimensional scaling (MDS), using the Bray-Curtis similarity index. Densities were previously transformed to logarithms to balance the contribution of rare and abundant species (CLARKE, 1993).

\section{RESULTS}

Diel variation between two shores and lunar cycles: caprellid amphipods. We found 13,224 caprellid amphipods in our study, 10,697 at Lamberto and 2,527 at Perequê. We found two caprellids in the shores, Caprella scaura Templeton, 1836 and Paracaprella pusilla Mayer,
1890, with dominance of $C$. scaura (from 68.1 to $99.3 \%$ of all caprellids in each shore and period).

Densities of $C$. scaura varied significantly throughout the time in both moon phases, but between shores only in the new moon; the interaction, however, was significant only in the full moon (Tab. I). During new moon, densities at Perequê were low, except for a peak of activity at around 03:00 am, whereas at Lamberto there were two marked activity peaks, at around 6:00 pm and 03:00 am (Fig. 1). There were also two activity peaks at Lamberto during full moon, around 3:00 pm and 03:00 am, whereas at Perequê there was a high density at 12:00 am and a sudden reduction afterwards (Tab. I, Fig. 1).

On the other hand, $P$. pusilla densities were not significantly different throughout the time in both phases of the moon, although there was a trend for peaks around 3:00 pm and 03:00 am during full moon (Tab. I, Fig. 1). Densities of $P$. pusilla were significantly higher at Lamberto when compared with Perequê (Tab. I).

No correlation was observed between density oscillation of these caprellids and the sunrise or sunset times.

Diel variation in assemblage composition between two shores: gammarid amphipods. A total of 65,218 gammarid amphipods were found in this study (60,896 at Lamberto and 4,322 at Perequê). The composition of gammarid assemblages differed between shores, with dominance of Erichtonius brasiliensis (Dana, 1853) and Gammaropsis atlantica Stebbing, 1816 at Lamberto and E. brasiliensis, G. atlantica, and Protohyale nigra (Haswell, 1879) at Perequê (Tab. II). The other species occurred in low densities during both periods.

The six most abundant species were analyzed to evaluate if their densities varied in time at both shores. There were no significant differences in densities during the day at both shores, nor significant interaction for Monocorophium acherusicum (Costa, 1857), Cymadusa filosa Savigny, 1816, Elasmopus pectenicrus (Bate, 1862) and E. brasiliensis (Tab. III, Fig. 2). These four species occurred in higher densities at Lamberto, with a strong trend for higher densities near high tides, at 3:00 pm and 03:00 am, with the exception of $C$. filosa (Fig. 2). No pattern on density variation was detected for these four species

Table I. Results of ANOVA comparing diel variation in densities of caprellid amphipods associated with Sargassum stenophyllum at two shores in Southeastern Brazil, in two phases of the moon (df, degrees of freedom; $F$, ANOVA F-test; MS, mean square; ${ }^{\text {ns }}, \mathrm{p}>$ $0.05 ; *, \mathrm{p}<0.01 ; * *, \mathrm{p}<0.001)$.

\begin{tabular}{|c|c|c|c|c|c|}
\hline \multirow[b]{2}{*}{ Source } & \multirow[b]{2}{*}{ df } & \multicolumn{2}{|c|}{ Full moon } & \multicolumn{2}{|c|}{ New moon } \\
\hline & & MS & $F$ & MS & $F$ \\
\hline \multicolumn{6}{|c|}{ Caprella scaura } \\
\hline Shore & 1 & 0.144 & $3.00^{\mathrm{ns}}$ & 6.268 & $181.9 * *$ \\
\hline Time & 7 & 0.237 & $4.92 *$ & 0.185 & $5.38 * *$ \\
\hline Interaction & 7 & 0.333 & $6.92 * *$ & 0.076 & $2.21^{\mathrm{ns}}$ \\
\hline Error & 32 & 0.048 & & 0.034 & \\
\hline \multicolumn{6}{|c|}{ Paracaprella pusilla } \\
\hline Shore & 1 & 0.755 & $17.68 * *$ & 0.040 & $12.89 *$ \\
\hline Time & 7 & 0.019 & $0.45^{\mathrm{ns}}$ & 0.002 & $0.71^{\mathrm{ns}}$ \\
\hline Interaction & 7 & 0.014 & $0.33^{\mathrm{ns}}$ & 0.002 & $0.66^{\mathrm{ns}}$ \\
\hline Error & 32 & 0.043 & & 0.003 & \\
\hline
\end{tabular}


at Perequê. On the other hand, there was a significant interaction between shore and sampling time for both $G$. atlantica and P. nigra (Tab. III). Densities of G. atlantica at Lamberto reached maximum values near high tides at 3:00 pm, with a lower peak at 03:00 am, whereas at Perequê there was a high density at 01:30 pm, and low densities afterwards (Fig. 2). Protohyale nigra was more abundant at Perequê, increasing its density during the night from low to high tides, decreasing after the high tide peak and increasing again at 10:30 am (Fig. 2). Here, the sunrise and sunset times did not influence gammarids densities as occurred with caprellids.

Table II. Composition (in percentage) of gammarid amphipod assemblages associated with Sargassum stenophyllum at two shores in Southeastern Brazil, during day and night samples with full moon.

\begin{tabular}{|c|c|c|c|c|}
\hline \multirow[b]{2}{*}{ Species } & \multicolumn{2}{|c|}{ Lamberto } & \multicolumn{2}{|c|}{ Perequê } \\
\hline & Day & Night & Day & Night \\
\hline Atylus minikoi (Walker, 1905) & 0.01 & 0.00 & 0.00 & 0.00 \\
\hline Batea catharinensis Muller, 1865 & 0.02 & 0.01 & 0.00 & 0.00 \\
\hline Monocorophium acherusicum (Costa, 1857) & 1.48 & 1.65 & 4.81 & 7.73 \\
\hline Cymadusa filosa Savigny, 1816 & 0.93 & 1.36 & 4.04 & 2.26 \\
\hline Elasmopus pectenicrus (Bate, 1862) & 0.90 & 0.87 & 1.10 & 0.38 \\
\hline Erichtonius brasiliensis (Dana, 1853) & 65.30 & 77.20 & 33.66 & 54.47 \\
\hline Gammaropsis atlantica Stebbing, 1816 & 30.51 & 18.53 & 41.17 & 4.25 \\
\hline Protohyale nigra (Haswell, 1879) & 0.09 & 0.19 & 13.37 & 27.55 \\
\hline Leucothoe spinicarpa (Abildgaard, 1798) & 0.22 & 0.16 & 0.50 & 0.02 \\
\hline Podocerus sp. & 0.53 & 0.02 & 0.34 & 1.69 \\
\hline Stenothoe valida (Dana, 1853) & 0.02 & 0.02 & 1.01 & 1.65 \\
\hline
\end{tabular}

\section{Lamberto}

\section{Caprella scaura}

\section{Perequê}
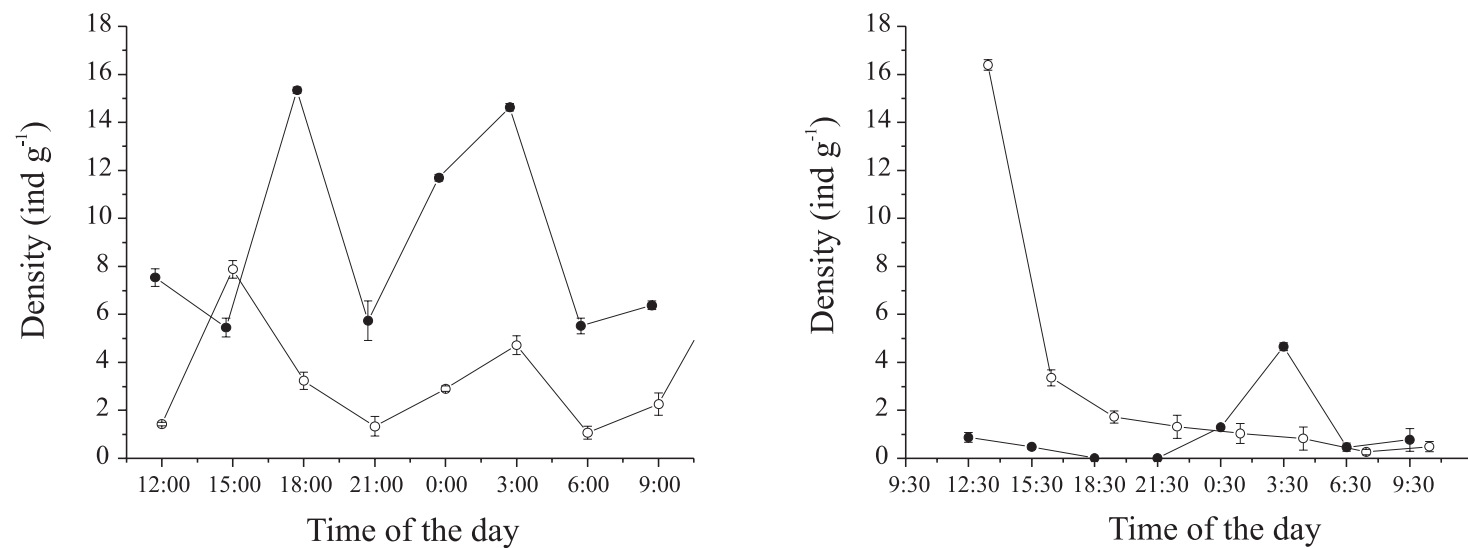

\section{Paracaprella pusilla}
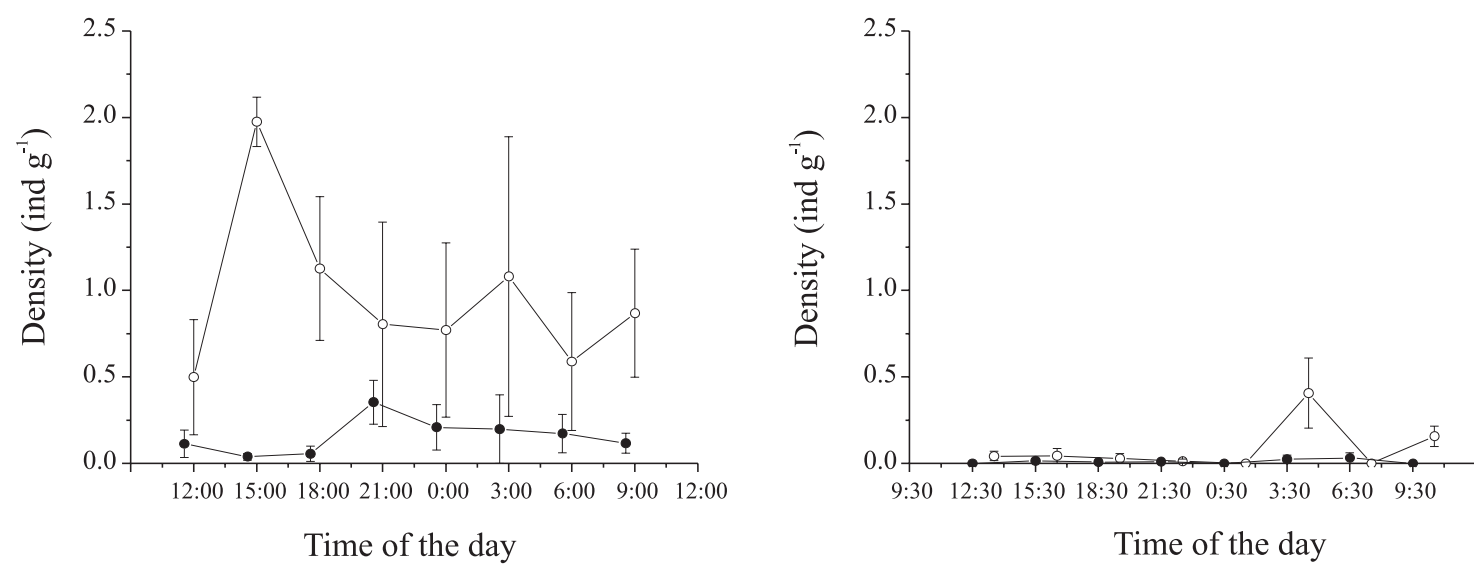

Time of the day

Fig. 1. Diel variation in mean densities $( \pm$ SE) of caprellid amphipods associated with Sargassum stenophyllum at two shores (Lamberto and Perequê) in Southeastern Brazil, during full moon (open symbols) and new moon (closed symbols) samples. 
The different patterns of variation exhibited by the amphipod species resulted in a low-defined pattern of variation for the assemblage. At Lamberto, there were differences between diurnal and nocturnal samples, with the exception of the 09:00 am sample, which was more similar to those samples obtained at night (Fig. 3). The
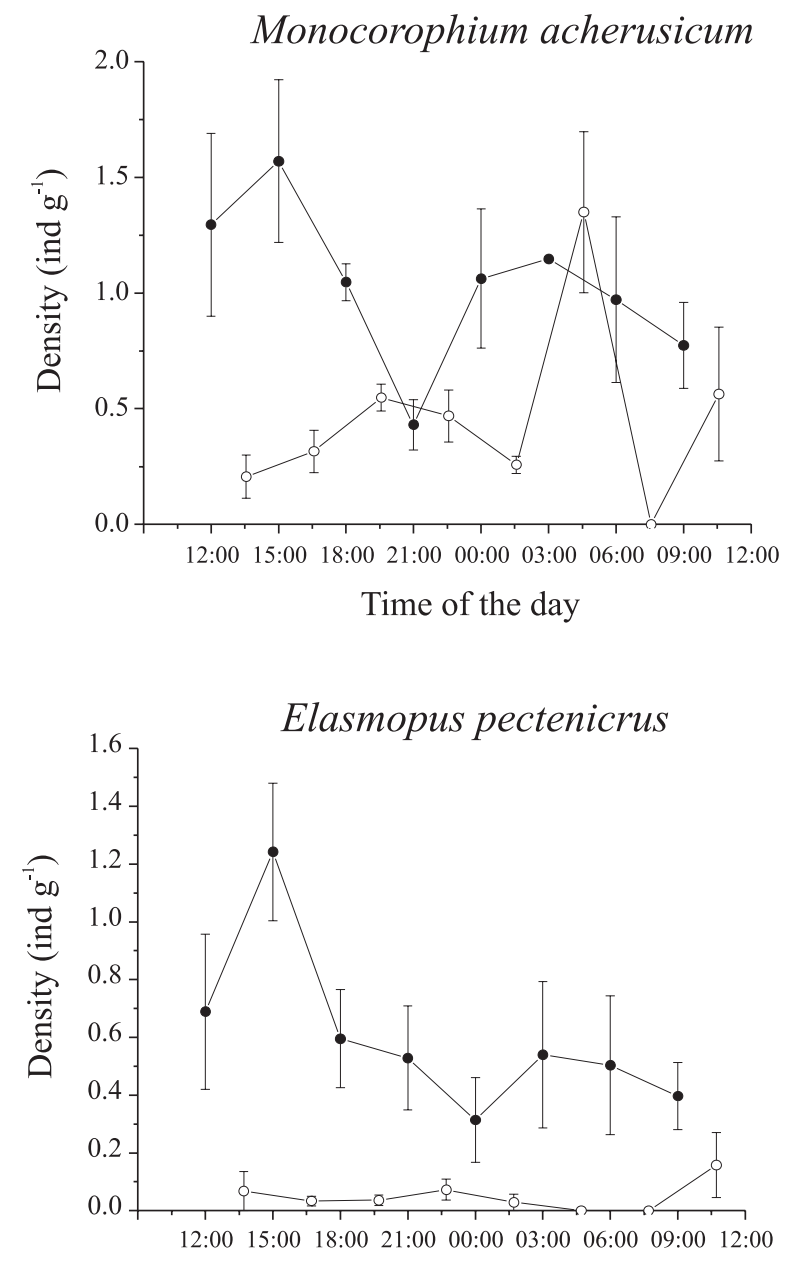

Time of the day

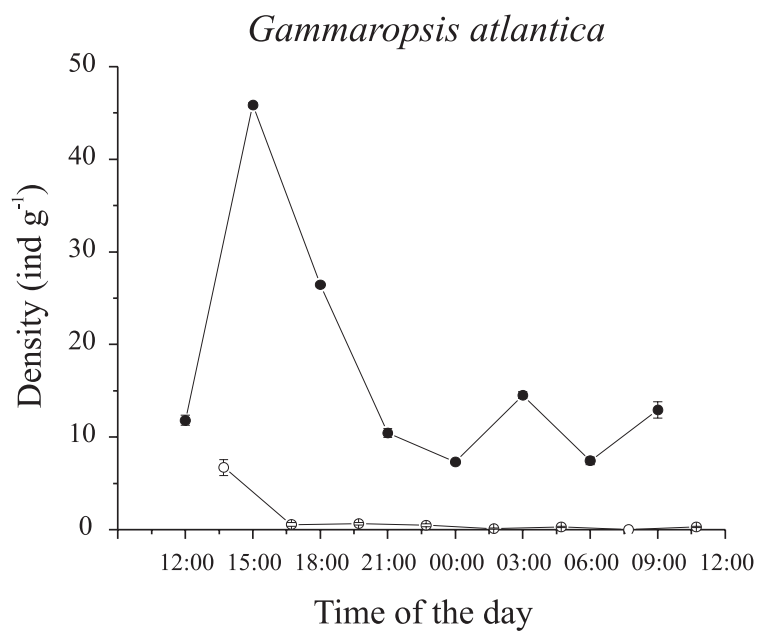

composition of the assemblages at Perequê varied strongly, with the largest differences recorded for samplings made at 07:30 am, when low densities of amphipods were observed (Fig. 2). The assemblages found in the six previous periods, from 1:30 pm to 04:30 am, varied gradually in structure and composition (Fig. 3).
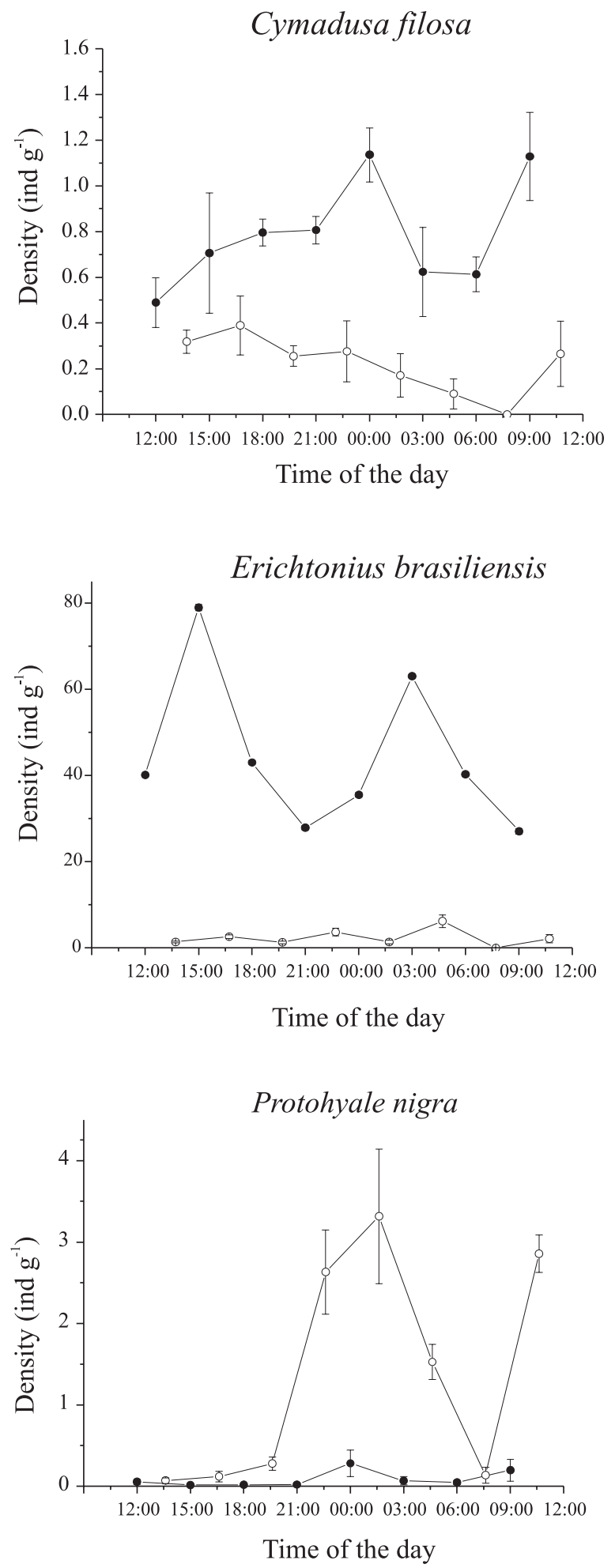

Fig. 2. Diel variation in mean densities $( \pm \mathrm{SE})$ of dominant gammarids associated with Sargassum stenophyllum at two shores in Southeastern Brazil, Lamberto (closed symbols) and Perequê (open symbols). 
Table III. Results of ANOVA comparing diel variation in densities of gammarid amphipod species associated with Sargassum stenophyllum at two shores in Southeastern Brazil, during full moon samples (df, degrees of freedom; $F$, ANOVA F-test; MS, mean square; ${ }^{\text {ns }}, \mathrm{p}>0.05$; $*, \mathrm{p}<0.01 ; * *, \mathrm{p}<0.001)$

\begin{tabular}{|c|c|c|c|c|c|c|c|}
\hline Source & $\mathrm{df}$ & MS & $F$ & MS & $F$ & MS & $F$ \\
\hline & & \multicolumn{2}{|c|}{ Monocorophium acherusicum } & \multicolumn{2}{|c|}{ Cymadusa filosa } & \multicolumn{2}{|c|}{ Elasmopus pectenicrus } \\
\hline Shore & 1 & 0.272 & $12.9 * *$ & 0.325 & $42.20 * *$ & 0.383 & $35.98 * *$ \\
\hline Time & 7 & 0.024 & $1.2^{\mathrm{ns}}$ & 0.009 & $1.2^{\mathrm{ns}}$ & 0.007 & $0.7^{\mathrm{ns}}$ \\
\hline Interaction & 7 & 0.029 & $1.4^{\mathrm{ns}}$ & 0.007 & $0.9^{\text {ns }}$ & 0.009 & $0.8^{\mathrm{ns}}$ \\
\hline \multirow[t]{2}{*}{ Error } & 32 & 0.021 & & 0.008 & & 0.011 & \\
\hline & & \multicolumn{2}{|c|}{ Erichtonius brasiliensis } & \multicolumn{2}{|c|}{ Gammaropsis atlantica } & \multicolumn{2}{|c|}{ Protohyale nigra } \\
\hline Shore & 1 & 16.424 & $148.1 * *$ & 11.202 & $200.9 * *$ & 0.861 & $35.8 * *$ \\
\hline Time & 7 & 0.160 & $1.4^{\mathrm{ns}}$ & 0.238 & $4.3^{*}$ & 0.131 & $5.5^{* *}$ \\
\hline Interaction & 7 & 0.103 & $0.9^{\mathrm{ns}}$ & 0.197 & $3.5^{*}$ & 0.090 & $3.7 *$ \\
\hline Error & 32 & 0.111 & & 0.056 & & 0.024 & \\
\hline
\end{tabular}

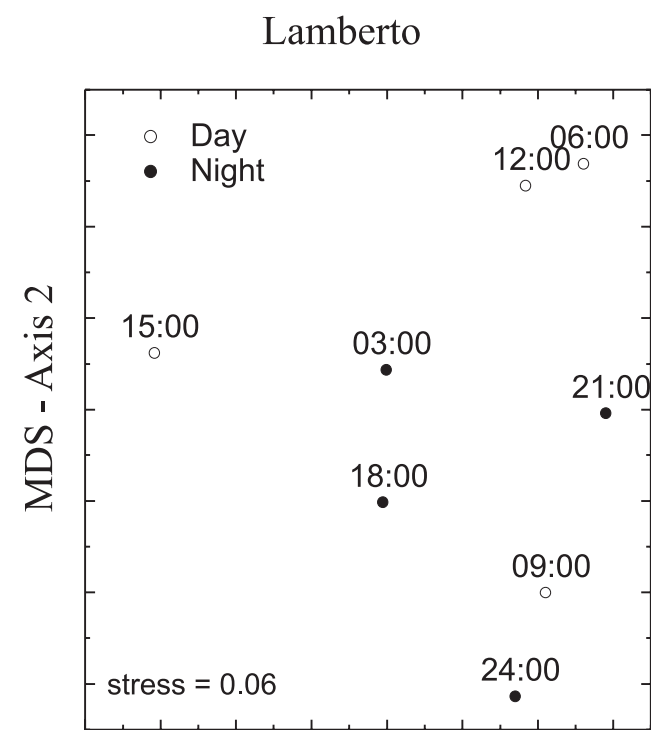

Perequê

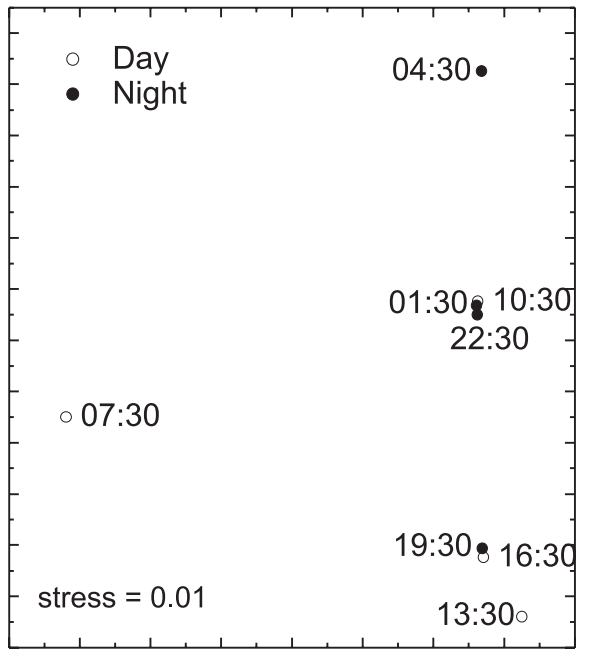

MDS - Axis 1

Fig. 3. Ordination by multidimensional scaling (MDS) of gammarid assemblages associated with Sargassum stenophyllum at two shores in Southeastern Brazil, sampled during 3-hour intervals, starting at 12:00h at Lamberto and 13:30h at Perequê. Values indicate the time of sampling.

\section{DISCUSSION}

Several studies suggest that the density of the fauna associated with macrophytes varies during the day, with more individuals at night (TAYLOR, 1998; SÁNCHEZJEREZ et al., 1999). In our study, we found no evidence of this pattern, since no species presented higher densities only at night, but with peaks of abundance also recorded during daylight hours. These results were similar for caprellids during the phases of new and full moon, so that no effect of the moon in the activities of amphipods was detected. However, peaks of density of caprellids and most gammarids at Lamberto, one during the day (around 3:00 pm) and the other at night (03:00 am), were coincident with or just after high tide times.

The differences in activity patterns of mobile epifauna associated with macrophytes have been mainly attributed to the activity of visually-oriented predators, which would exert a greater consumption pressure during the day (ROBERTSON \& HowARD, 1978). Thus, activities of the mobile fauna such as feeding, reproduction and dispersal should be more concentrated in nocturnal periods (Rogers et al., 1998; JøRGENSEN \& CHRISTIE, 2003). However, few works evaluated this hypothesis, which was generally tested through observational studies. For example, RoGERs et al. (1998) evaluated the activities of mesograzers during the day and at night, and found a higher proportion of sighted individuals at night. However, the effects of predators on prey behavior are generally complex, and indirect effects can be common. DAwIDOWICZ \& Loose (1992) found more migration of zooplankton with the presence of predators than in controls without predators, indicating that chemical cues can be involved in the vertical migration.

In the present study, we compared two shores with distinct degrees of turbidity, and expected that the activity of visually-oriented predators would have a greater influence at Perequê, where the water is clear. Amphipod densities were lower in this shore, but many other factors could influence general density differences (TANAKA \& LeITE, 2003). Further, there was no evidence of greater nocturnal activities at Perequê. P. nigra was the only 
species that showed a strong increase in densities at night, as expected if visually-oriented predators influence the associated fauna. However, another density peak occurred during the day, suggesting that other factors can also influence the activities of this species.

BUSCHMANN (1990) found nocturnal increase of Hyale spp. densities at night on beds of the morphologically simple Iridaea laminarioides (Iridae), a preferred food resource of these amphipods, whereas no differences between day and night were found for amphipods on a turf-forming species, Ulva rigida (Ulvacea). Thus, diel activities of algalassociated amphipods can be influenced by the availability of refuges in different shores or within a shore. However, we found no indication that differences in amphipod life styles influenced the activity patterns, since both tube-builders such as G. atlantica and nestlers such as P. nigra presented variation during the day.

The density peaks found both during the day and at night for most amphipods in the present study suggest that, for this system, diel variation on mobile epifaunal densities can be related mostly with tidal levels. In fact, the highest densities of most species were found during high tides, mainly during daytime hours. DAVENPORT et al. (1999) found that emersion of intertidal seaweeds results in loss of mobile epifauna, and that this effect would be less pronounced for more complex algal species, which retain more water during low tides. Changes in the structure of shallow water communities such as salt marshes (HAMPEL et al., 2003) and intertidal rocky shores (DAVIDSON et al., 2004) were also recorded. Although $S$. stenophyllum occurs in the sublittoral, during very low tides some plants can be exposed, possibly influencing the distribution of epifauna. Diurnal low tides in the austral autumn and winter seasons are common in this region, and may be an important factor of macroalgae mortality during these periods (SCHENKMAN, 1989). Thus, tidal height changes can influence diel activity patterns of mobile species, with stronger effects when tidal amplitude is large, such as in spring tides (HAMPEL et al., 2003), or when low tides occur during the day, as discussed above. These factors can probably influence the structure of phytal assemblages, contributing to dynamics at different time scales (DAVIDSON et al., 2004). Further studies are thus necessary to properly understand the activity patterns of macrophyte-associated mobile species.

Acknowledgments. We thank to FAPESP for the undergraduate fellowships to Daniela B. Sudatti (Proc. 98/007448) and Raquel S. Gebara (Proc. 97/00945-0). We also thank to Dr. S. Masunari (Universidade Federal do Paraná) and to an anonymous referee for comments on an earlier version of the manuscript.

\section{REFERENCES}

Alldredge, A. L. \& KIng, J. M. 1985. The distance demersal zooplankton migrate above the benthos: implications for predation. Marine Biology 84(3):253-260.

BuschmanN, A. H. 1990. Intertidal macroalgae as refuge and food for Amphipoda in central Chile. Aquatic Botany 36(3):237-245.

Clarke, K. R. 1993. Non-parametric multivariate analysis of changes in community structure. Australian Journal of Ecology 18(1):117-143.

Connolly, R. M. 1997. Differences in composition of small, motile invertebrate assemblages from seagrass and unvegetated habitats in a southern Australian estuary. Hydrobiologia 346(1-3): 137-148

Davenport, J.; Butler, A. \& Cheshire, A. 1999. Epifaunal composition and fractal dimensions of marine plants in relation to emersion. Journal of the Marine Biological Association of the United Kingdom 79(2):351-355

Davidson, I. C.; Crook, A. C. \& Barnes, D. K. A. 2004 Macrobenthic migration and its influence on the intertidal diversity dynamics of a meso-tidal system. Marine Biology 145(4):833-842

Dawidowicz, P. \& Loose, C. J. 1992. Metabolic costs during predator-induced diel vertical migration of Daphnia. Limnology and Oceanography 37(8):1589-1595

EDGAR, G. J. 1983. The ecology of south-east Tasmanian phytal animal communities. I. Spatial organization on a local scale. Journal of Experimental Marine Biology and Ecology 70(2):129-157.

Guest, M. A.; Connolly, R. M. \& Loneragan, N. R. 2003. Seine nets and beam trawls compared by day and night for sampling fish and crustaceans in shallow seagrass habitat. Fisheries Research 64(2):185-196.

Hampel, H.; Cattrissse, A. \& Vincx, M. 2003. Tidal, diel and semilunar changes in the faunal assemblage of an intertidal salt marsh creek. Estuarine, Coastal and Shelf Science 56(34):795-805.

Harari, J. \& Mesquita, A. R. De. 1996. Tabuas de Marés para Cananéia, Ubatuba e Santos, anos de 1996 e 1997. Relatório Interno do Instituto Oceanográfico, IOUSP 37:1-22.

HAY, M. E. 1997. The ecology and evolution of seaweed-herbivore interactions on coral reefs. Coral Reefs 16(supp.1):S67-S76.

Hay, M. E.; Duffy, J. E.; Pfister, C. A. \& Fenical, W. 1987. Chemical defense against different marine herbivores: are amphipods insect equivalents? Ecology 68(6):1567-1580.

HAYs, G. C. 2003. A review of the adaptive significance and ecosystem consequences of zooplankton diel vertical migrations. Hydrobiologia 503(1-3):163-170.

Jørgensen, N. M. \& Christie, H. 2003. Diurnal, horizontal and vertical dispersal of kelp-associated fauna. Hydrobiologia $\mathbf{5 0 3}(1-3): 69-76$

Linke, T. E.; Platell, M. E. \& Potter, I. C. 2001. Factors influencing the partitioning of food resources among six fish species in a large embayment with juxtaposing bare sand and seagrass habitats. Journal of Experimental Marine Biology and Ecology 266(2): 193-217.

Moore, P. G. 1978. Turbidity and kelp holdfast Amphipoda. I. Wales and S. W. England. Journal of Experimental Marine Biology and Ecology 32(1):53-96

Nelson, W. G. 1979. Experimental studies of selective predation on amphipods: consequences for amphipod distribution and abundance. Journal of Experimental Marine Biology and Ecology 38(1):225-245.

PARKER, J. D.; DufFY, J. E. \& ORTh, R. J. 2001. Plant species diversity and composition: experimental effects on marine epifaunal assemblages. Marine Ecology Progress Series 224:55-67.

RoBERTSON, A. I. \& Howard, R. W. 1978. Diel trophic interactions between vertical-migrating zooplankton and their fish predators in an eelgrass community. Marine Biology 48(3):207-213.

Rogers, C. N.; Williamson, J. E.; Carson, D. G. \& Steinberg, P. D. 1998. Diel vertical movement by mesograzers on seaweeds. Marine Ecology Progress Series 166:301-306.

Sánchez-Jerez, P.; Barberá-Cebrián, C. \& Ramos-Esplá, A. 1999. Daily vertical migrations in the epifauna associated with Posidonic oceanica meadows. Journal of the Marine Biological Association of the United Kingdom 79(6):971-977.

Schenkman, R. P. F. 1989. Hypnea musciformis (Rhodophyta): ecological influence on growth. Journal of Phycology 25(1):192-196.

Széchy, M. T. M. De \& Paula, E. J. DE 2000. Padrões estruturais quantitativos de bancos de Sargassum (Phaeophyta, Fucales) do litoral dos estados do Rio de Janeiro e São Paulo, Brasil. Revista Brasileira de Botânica 23(2):121-132.

TANaKa, M. O. \& Leite, F. P. P. 1998. The effect of sieve mesh size on the abundance and composition of macrophyteassociated macrofaunal communities. Hydrobiologia 389(13):21-28.

2003. Spatial scaling in the distribution of macrofauna associated with Sargassum stenophyllum: variation on faunal groups, gammarid life habits, and assemblage structure. Journal of Experimental Marine Biology and Ecology 293(1): $1-22$

TAYLOR, R. B. 1998. Short-term dynamics of a seaweed epifaunal assemblage. Journal of Experimental Marine Biology and Ecology 227(1):67-83. 